\title{
Indiscipline and Academic Achievement Among Secondary School Students in Kilifi County, Kenya: A Correlational Study
}

\author{
Jane Waithira Karimi Dr. Jacinta Aswani Kwena Dr. Alice Anika \\ School of Education, Pwani University, P.O Box 195, Kilifi, Kenya \\ * E-mail of the corresponding author: janludoh@gmail.com
}

\begin{abstract}
Secondary school student, academic achievement has received little research attention in relation to indiscipline. The main objective of this study is to establish the relationship between indiscipline and academic achievement among public secondary school students in Kilifi County. Correlational research design was adopted. The target population was year 2018 form four students in public secondary schools in Kilifi County. Purposive, simple random and cluster sampling procedures were used in the selection of schools, teachers and students. The study sample size was about 279, comprised of 145 girls and 126 boys, six class teachers and two discipline masters. Data was collected using discipline scale for teachers and students. Students' academic achievements data was obtained from mean scores of the end of second-term examination. Data analysis was done using both descriptive and inferential statistical procedures. The results revealed a strong negative relationship between indiscipline and academic achievement; slight differences of the indiscipline mean score between male and female participants was also found. Recommendation of the study was that parents, teachers and the society as a whole should corporate and help to reduce incidences of indiscipline behaviors among students, so as to give students stable mind to learn in order to perform well academically.
\end{abstract}

Key words: Indiscipline, academic achievement, relationship, secondary schools students.

DOI: $10.7176 / \mathrm{JEP} / 11-12-15$

Publication date: April $30^{\text {th }} 2020$

\section{Introduction}

Education, transformation and successful life of an individual is a necessity and a priority area for development in the world today. To attain this, appropriate skills, values, attitudes, knowledge and certain competencies must be instilled into the individuals. If this happens social, economic and political development of the nation at large is realized. It is through the education system that nations impart to their people the aspirations that will produce the citizen of their choice. In Kenya equally, there is high value attached to secondary school education. The government and the public in Kenya heavily invest in it as this level of education prepares learners for advanced studies, further training and the world of work. At individual level, high school education assists learners to develop mentally, socially, morally, physically and spiritually which is depicted by the ability in academics, social relations with others as well as co- curricular activities such as clubs, games and sports. Secondary school education promotes environmental and health practices and also gives room for identification of various talents to an individual student. It is also regarded as a transitional stage for higher education and training. These simple facts explain why researchers and scholars, all over Kenya, continue to do research into ways of improving human knowledge and development.

Regrettably, issues of behavior problems in the society have been reported as major factors that negatively affect the trend of academic achievement and development globally. These behavior problems take the form of indiscipline which is a common phenomenon in many high schools today (Anya, 2016; Itatu, 2015). Lack of discipline is called indiscipline and is any action considered to be wrong and not generally accepted as proper in the society (Njoroge and Nyabuto, 2014). Across the world acts of student indiscipline in many public schools has multiplied causing great concern among education administrators, educators, teachers and stakeholders and to a lesser extent for learners themselves, parents and the general public (Karanja \& Bowen, 2012; Ngwokabuenui, 2015; Thinguri, 2015). In the school setting indiscipline is manifested in various ways like in absenteeism, rudeness, bullying, lateness, drug abuse, truancy and also by strikes that result into massive destruction of school properties. Additionally, schools today have to deal with the problem of weapons, recruitment into criminal groups, rivalry, drugs and substance abuse, trafficking and youth radicalization ( Omote, Thinguri \& Moenga, (2015). These cases are experienced all over the world with USA leading in the rate of school crimes compared to other countries like Canada and Britain especially in the use of weapons (Kute, 2014). However, indiscipline among students in public high schools has persisted over the years throughout the world, Kenya inclusive (Omote et., al. 2015). Currently, in Kenya students have been involved in burning school facilities including dormitories, libraries, laboratories which have been related to unpreparedness and incompetence to tackle KCSE. According to Odour (2016), the 
ministry of education established panic about expected strict exam supervision as a major cause for unrest in schools. Kilifi County, one of the 47 counties in Kenya has so far experienced indiscipline problems which have been attributed to social-cultural and social economic activities (Karuke, 2012).The County has also experienced a series of major destructive strikes in a span of two years as documented in Table 1.

Table 1 shows a list of Public secondary schools in Kilifi County where unrest has been experienced in the years 2014 to 2016.

. Table 1. Cases of unrest and strike

\begin{tabular}{lllll}
\hline Year & School & Status & Indiscipline & Damages \\
\hline $\mathbf{2 0 1 4}$ & Lutsangani & Girls & Boycott of exams & Burnt infrastructure \\
$\mathbf{2 0 1 4}$ & Dzitsoni & Mixed & Boycott of exams & Destruction of property \\
$\mathbf{2 0 1 5}$ & Chasimba & Mixed & Boycott of exams & Burnt dormitory \\
$\mathbf{2 0 1 5}$ & Ganze & Girls & Boycott of exams & Minor destruction of property \\
$\mathbf{2 0 1 5}$ & Jaribuni & Mixed & Boycott of exams & Burnt school infrastructure \\
$\mathbf{2 0 1 5}$ & Malindi & Boys & Boycott of exams & Destruction of property \\
$\mathbf{2 0 1 5}$ & Sokoke & Boys & Boycott of exam & Burnt school infrastructure \\
$\mathbf{2 0 1 5}$ & Vitengeni & Mixed & Boycott of exam & Burnt school infrastructure \\
\hline
\end{tabular}

Sources: County Education Office, (2016)

Indiscipline problems are responsible for significant loss of instructional time and school property and this then has a spiral effect on the student's performance in examination among other negative effects (Adams, Lemaire \& Prah, 2013; Omote et., al. 2015). The unacceptable behavior among students may prevent them from concentrating in class, lose content and knowledge taught, might create tension and insecurity in class as well as disrupting lessons leading to use of most of the contact hours in settling disputes. As a result this may not allow complete coverage of syllabus before students write their exams (Achiaa, Asamoah, Ofori \& Tordzro, 2018). In addition, meaningful teaching and learning geared towards the attainment of school goals is unattainable if students are not disciplined. According to Mwaniki (2018), discipline is a basic requirement for successful teaching and learning in schools and it is therefore vital for student's academic achievement; the stakeholders in schools should in a participatory approach probe into the root causes of identified students' indiscipline in schools with an aim to reverse the trends. Fareo and Ballah (2018) further observed that indiscipline in school greatly affects the quality of teaching and learning which results to poor results, dropouts, and wastage of resources invested by stakeholders of education such as parents, and the government. Further noted that indiscipline of students could lead to closure of schools, wanton destruction of property corruption of differ kinds, moral decadence and loss of lives. The parents, school authorities, the society and the government should take proactive measures against this social menace by ensuring that good behavior and conditions are inculcated, established and maintained for effective learning in schools. According to Mukami, (2013) indiscipline should be dealt with in schools as it influences students' performance. Further noted that major indiscipline cases are observed in secondary schools rather than primary; when students notice certain biological changes signaling maturity in the course of the growth and development, they tend to misbehave by faulting school rules and regulations. Gitome, Katola and Nyabwari (2013) further asserted that students in secondary schools are still in the age of rapid physical, social, psychological and physiological developments. These developments are accompanied with variety of changes which if not well attended to lead to indiscipline which can negatively affect concentration on studies. This study therefore, focused on the correlation between indiscipline and academic achievement among secondary school students in Kilifi County.

\section{Statement of the problem}

The Government of Kenya has invested heavily in secondary school education but the outputs of this investment do not correspond to the inputs in terms of the learners' academic achievement in some parts of the country. There has been continued poor academic achievement among students in national examinations especially in secondary 
schools, for example, in Kilifi County where they have constantly scored an average of grade D in KCSE (County Education Office, 2016). This has had far reaching implications for the students in terms of chances for further education and even more rewarding life opportunities. The Government of Kenya through the Ministry of Education (MoE) has made efforts to curb the various indiscipline cases in learning institutions. Guidance and counseling units had been implemented in all secondary schools (GoK, 2005). Deployment of qualified teachers had been done as well. Other stakeholders including the parents have also attempted similar efforts to solve indiscipline problems. Disciplinary committees had also been set in the national level to help alleviate the indiscipline problems, and yet the situation had not improved. It is therefore important to focus on factors that are associated with low academic achievement.

The schools in Kilifi had been characterized by very destructive strikes year in year out. All these had immensely contributed to lack of skilled human resource, and difficulties in meeting demands for wealth production in the county. Could it be that these indiscipline problems have a relationship with the academic achievement in the County?

From the foregoing background of the study, there has been substantial evidence that indiscipline has been a major concern globally and it affects the academic achievement of students negatively, citing that students' indiscipline prevent them from concentrating in class, lose the content taught, disruption of learning time leading to lose of learning time. Thus, this results to failure of syllabus coverage before exam writing which translates to minimal performance of the students. (Achiaa, Asamoah, Ofori \& Tordzro, 2018; Fareo \& Ballah, 2018; Mwaniki, 2018; Njoroge \& Nyabuto, 2014). Additionally major indiscipline cases are recorded in secondary schools and not in primary schools, as this is the period when most changes in developmental course take place. Notably, secondary school students' academic achievement has received little research attention in relation to indiscipline in the county.

It is for these reasons that the researcher realized a great need to design a study to establish the relationship between, indiscipline and academic achievement among secondary school students in Kilifi County with a hope that this may positively change the academic achievement in the County.

\section{Literature review}

Indiscipline is a destructive behavior which does not promote peace and co-existence in society. This behavior is a canker to many nations in the world as it is a threat to the lives of the young ones. Many efforts have been made by several world leaders to curtail this growing notoriety especially among school children but it is regrettable to say that there is no single day the media will not report of incidence of indiscipline in newspapers, on the radio and television (Clinard \& Meier, 2015). Mwaniki (2018) noted that indiscipline is one of the social problems among the students as they set aside the school rules and regulations and do what they like and leave undone what they are expected to do. Findings from various studies reveal that student indiscipline is experienced in both secondary and primary schools globally (Itatu, 2015; Ngwokabuenui, 2015; Rahimi \& Karkami, 2015). A study by Whisman and Hammer (2014) carried out in West Virginia demonstrated that disciplinary involvement increases the students' likelihood of performing poorly academically. The association between disciplinary involvement and academic performance varied by student characteristics. Additionally, Baumann \& krskova (2016) in the study findings demonstrated significant differences in discipline for low, medium and high performing students. Peak-performing students had the highest level of discipline. Further, the findings provided that good discipline allows students to work well and this ultimately leads to better academic performance.

In Africa, research has revealed serious problems of indiscipline in schools in various countries. A study by Okoroma (2015), for instance examined school indiscipline and student's academic achievement which was a case study of secondary schools in Port Harcourt Local Government area in Rivers State. The results showed that all the parameters of school indiscipline, that were considered in the study, contributed to low academic achievement of secondary school students. Results revealed truancy, persistent lateness, absenteeism, cult practices, drug use and abuse, drunkenness, delinquency, cheating, disobedience and sexual problems as the main indiscipline problems among students. The findings further revealed that the burden of student's indiscipline was on family, the school and the government. It was interesting to compare these findings with the current study's findings considering that some of the indiscipline parameters have been considered too. Similarly, Ethaine (2014), carried out a study among secondary school students in Lagos, Nigeria and observed that indiscipline among learners was high and was experienced at all levels including primary schools thus negatively affected academic performance of the students. In addition, Achiaa, Asamoah, Ofori, and Tordzro (2018) investigated the effects of indiscipline on academic performance of Junior school students in Ghana. The study revealed that indiscipline negatively affected academic achievement, citing the students' inability to concentrate in class, loss of materials taught due to absenteeism and increase in rate of school drop-out. 
Indiscipline in Kenyan schools has been one of the challenges facing schools and has negatively affected academic performance and general lives of the students and the society at large (Njoroge \& Nyabuto, 2014). Research has been conducted relating to indiscipline among high school students, recommendations made, and measures taken to curb this problem, yet incidences resulting from indiscipline keep on increasing year by year and taking different forms. (Ekombe, 2010; Mwaniki, 2018; Karanja, 2012; Likoye, 2016; Oduor, 2016). These scholars listed causes of unrest in secondary schools as poor administration, strict school rules and regulations, poor teacher-student relationships, communication challenges, peer pressure and influence, poor diet, ineffective teaching methods, drug abuse, over-protective guardians, inconsistency of punishments, poor parental care and prefects' indiscipline. Recommendations to eradicate indiscipline in schools was made. Itatu (2015) in a study on the effects of indiscipline on academic performance among secondary schools in Mutito Sub-County in Kitui observed that schools where students went on strike showed higher variation in the mean grade when compared to schools where students had not gone on strike. The data clearly showed that strikes led to poor academic performance. A study by Anya, (2016) found that poor academic results, teenage pregnancy, physical and psychological deformity are glaring effects of student's indiscipline. The study recommended appreciation of good behavior performed by the students and use of suspension, expulsion and corporal punishment only when necessary in efforts to address the indiscipline problems that were realized in the school. Ouma, Serem and Simatwa, (2014) similarly observed that indiscipline was a major concern to educators and policy makers and noted that students with indiscipline problems perform poorly in their academics. The study recommended giving students adequate moral instructions and provision of guidance and counseling services. Ouma, et., al. (2014) further affirmed that if school is effectively disciplined, the academic performance on the part of the student and teacher will be highly rated. Additionally, Agak, Kabuka, and Simba, (2016) revealed that indiscipline affect the student's academic performance among primary school pupils. These studies recommended further investigation of indiscipline among learners globally and how it influences their academic performance. Ethaine (2014) concluded that effective school discipline should be encouraged in controlling student's behavior thus effects to students' general academic performance. Some studies however suggest that indiscipline has shown variance influence on students' academic performance (Gakure, Mukuria , Kithae, 2013; Jones, 2013).

The above reviewed literature has therefore presented varying and inadequate findings. Various studies have recommended further investigations on the indiscipline issue. In addition, few studies have correlated the variables using secondary school students as sample. This inspired the current research study in order to further investigate and determine the relationship between indiscipline and academic achievement among secondary schools students in Kilifi County with an aim of improving the performance as well as adding information on existing knowledge in this area.

\section{Research Methodology}

\subsection{Research Design}

Correlational research design was used in this study. The design was used to establish the relationship between indiscipline and academic achievement. According to Jackson, (2014) correlational designs allow researchers to describe the relationship between two measured variables.

\subsection{Study participants}

The study target was extra county secondary school where the total population was 2120 . The study sampled $13 \%$ equivalent to 279 participants of the population According to Gorard (2001), a sample size above 10 percent is considered appropriate. From the girls' school three class teachers and one discipline mistress; from the boy's school three class teachers and one discipline master were involved in the study. In total two schools were selected, 271 students, six class teachers and two discipline masters were involved in this study; giving a total of 279 participants in the study.

\subsection{Research instruments}

Data was collected using five instruments namely; Students' indiscipline scale, teacher's rating of students' indiscipline scale, discipline masters' interview guide and document analysis.

\subsection{Data collection procedure}

The researcher presented the research permit to the administration of the sampled schools, then familiarized with the school and established time for administration of the instruments. The researcher then sought consent from the students to administer the research tools. The identified participants were given instructions on the completion of the indiscipline scale with the assistance of the class teachers. The researcher also made effort to clarify some of the terms in the tools to make them clear for the respondents. The researcher then collected the instruments immediately after the participants filled them in. The scale for the class teachers were administered, data for 
absenteeism from the class registers with the help of the class teachers was obtained. The Interviews were conducted with the discipline masters at an appropriate agreed upon time. The interview was recorded to help the researcher capture all the information then transcription was done later. The data on the students' academic achievement was finally obtained from the records, from the selected schools' administration.

\subsection{Data analysis}

The study employed both qualitative and quantitative approach in data analysis. The qualitative data which was collected through the interviews was analyzed thematically. Quantitative data which was obtained from the scales was analyzed using both descriptive and inferential statistical. Descriptive statistics such as measures of central tendency, measures of variance and percentages were used to describe sample characteristics which were presented in figures and frequency tables. Inferential statistical procedures specifically Pearson Product Moment Correlation and multiple regression were used to test each hypothesis at $\alpha=0.05$.

\section{Data presentation and analysis}

Results were analyzed in line with the study objectives.

Table 2. Indiscipline self-ratings scores of the students

\begin{tabular}{lllll}
\hline & & Sex & & \\
\hline & Levels & Male & Female & Total \\
& Low & 18 & 10 & 28 \\
& Average & 35 & 70 & 105 \\
& High & 72 & 64 & 137 \\
Mean & & 69.86 & 69.58 & 69.71 \\
Std. Dev & & 9.65 & 5.78 & 7.80 \\
\hline $\mathrm{n}=270$ & & &
\end{tabular}

The information in Table 2 shows that 137 (50.6\%) of the participants' self- rated themselves high in indiscipline scale, $105(38.7 \%)$ rated themselves average, while only $28(10.3 \%)$ of the participants rated themselves as low in the indiscipline scale. Mukami (2013) affirmed that when secondary school students notice certain biological changes signaling maturity in the course of the growth and development, they tend to misbehave by faulting school rules and regulations. In addition, Bandura's (1977) theory of social Learning, posited that people learn from one another through observation, imitation, modeling and reproduction. Further concluded that the aggressive behavior in adolescents might have been learned through observation and imitation from the families where parents also displayed aggressive behavior. Consequently, these adolescents become aggressive in school and participate in strikes and riots (Bandura (1977) which are some of the indiscipline areas focused in the current study. (Bucher \& Lee 2011) in support noted that adolescents experience social and emotional changes; they tend to be argumentative and aggressive due to sudden and intense emotions. Similarly, Ekombe (2010) revealed that in a school setting students are believed to have learned their undesirable behavior from their day to day experiences or from the environment. The information from the interview conducted in this study with the discipline masters in support, attributed high indiscipline of the students to permissiveness in the community, parental over protection, and inability of the parents to meet their children economic needs as great contributors to the increase of indiscipline among students especially in high school. These findings supported the findings of a research by Achaa, Asamoah, Ofori, Tordzro (2018) which revealed that teachers, school factors and home factors such as broken homes, mass media, poor financial support from parents, bad examples set by parents and parents' inability to meet their children's psychological, emotional and social needs were blamed for the upsurge of indiscipline behaviors among high school students.

The findings on high levels of indiscipline were corroborated by more information given by the participants on other items on the indiscipline scale as evidenced in further analysis. For instance, $52.9 \%$ of the participants indicated that they severally got disciplined by the teachers compared to $36.1 \%$ who indicated that they were not often disciplined. Additionally, majority $(63 \%)$ of the participants indicated that they were absent in school less than five times in a term compared to $26 \%$ who indicated that they were never absent at all. Further, data on absenteeism indicated that $97.8 \%$ were categorized as having mild rate of absenteeism and $2.2 \%$ rated as moderate 
in the absenteeism rate however; no participant rated within chronic category of absenteeism. More information elicited from respondents revealed that they were absent from school due to school fees and sickness $(97.7 \%)$ and only $2.3 \%$ were absent due to suspension, more analysis, though showed that absenteeism did not contribute on indiscipline rate of the participants.

The indiscipline mean as presented in Table 2 gave 69.86 among males and 69.58 among females. This showed that the indiscipline mean mark of male was slightly higher than that of the female in this study. In terms of standard deviation the distribution of male participants was more spread compared to that of female. This is because the standard deviation (9.65) of male was higher than that of female (5.78). The findings was an indication that indiscipline issues exist in both girls and boys though in different levels. The differences may be rooted from physical behaviors, styles of social interaction and choices in adolescence which may have a variety of sources; primarily parents, peers and the media. Physically boys tend to be more active than girls, they are also more prone to rely on physical aggression if they are frustrated (Espelage \& Swearer, 2004). Boys therefore are found with behavior problems more than girls. In support (Mueni, 2015) concluded that boys were more affected by discipline issues in secondary school than girls in all types of schools that were involved in the study on factors that influenced discipline of both boys and girls in public secondary schools.

The findings of the current study agreed with the findings of related research work by Duckworth \& Seligman, (2006) who reported that girls are more self-discipline than boys as per delay of gratification measures, self-report, teacher and parent ratings. Additionally, Nekby, Thoursie, \& Vahtrik, (2015) who did a study on gender differences concluded that girls are more self-disciplined; citing that girls are more sensitive to differentiating conditions and factors and that they respond to issues cautiously than boys.

Levels of students indiscipline by age and sex was also analyzed as shown in Table 2.

Table 3. Level of indiscipline by age and sex

\begin{tabular}{lllll}
\hline & & Sex & & \\
\hline \multirow{2}{*}{ Age (Years } & Levels & & & Total \\
$16-17$ & Low & Male & Female & 2 \\
& Average & 0 & 2 & 25 \\
& High & 6 & 19 & 21 \\
$18-19$ & Low & 7 & 14 & 25 \\
& Average & 18 & 7 & 73 \\
20 and above & High & 26 & 47 & 96 \\
12 & Low & 53 & 43 & 1 \\
Total & Average & 0 & 1 & 8 \\
\hline Key: & High & 3 & 5 & 19 \\
& & 12 & 7 & $270(100 \%)$ \\
\hline
\end{tabular}

Key: \%- Percentage

Majority of the male participants aged 16 to 17 years were categorized as having high level of indiscipline at 7 $(53.8 \%)$ compared to female counterparts whose majority were categorized as average at $19(54.3 \%)$ as presented in Table 4.7. Equally majority of male participants aged 18 to 19 rated high in indiscipline 53 (56\%) compared to female participants in the same age who rated as average at $47(47.9 \%)$ in this scale. Ritchie (2017) noted that there are biological differences between male and female; males tend to form hierarchies naturally in attempt to have dominance or position in a group from an early age. In the same, Bucher \& Lee (2011) added that adolescents experience social and emotional changes; they tend to be argumentative and aggressive due to sudden and intense emotions. This may result to antagonistic and conflictual behavior problems which may be depicted in their indiscipline levels.

\subsection{Relationship between emotional intelligence and academic achievement.}

This was done by computing Pearson product moment correlation test. The results are presented in the Table 3. 
Table 3. Relationship between academic achievement and indiscipline levels of the students.

\begin{tabular}{llll}
\hline & & Academic Achievement & Indiscipline Level \\
\hline Academic Achievement & Pearson Correlation & 1 & $-.531^{*}$ \\
& Sig (2-tailed) & & .000 \\
& & & \\
& & 1 \\
Indiscipline Level & Pearson Correlation & $-.531 *$ & \\
& Sig (2-tailed) & .000 &
\end{tabular}

Results in Table 3 showed that there was a strong negative relationship between level of indiscipline and student academic achievement, $\mathrm{r}=-.531^{*}, \mathrm{n}=270, \mathrm{p}<0.05$. These results indicated that the indiscipline students perform poorer academically than those who are disciplined. This implied that student's level of indiscipline has significant negative influence on the academic performance.

The study confirmed previous research that has been documented. For instance, Achiaa, Asamoah, Ofori, and Tordzro (2018) investigated the effects of indiscipline on academic performance of Junior school students in Ghana. The study revealed that indiscipline negatively affected academic achievement. Additionally, Karuke (2012) revealed that indiscipline affected academic achievement negatively. The study encouraged that students indiscipline should be eradicated as a strategy of improving the pupils' academic achievement. Agak, Kabuka,Simba (2016) similarly, found that there was a moderate relationship between pupils discipline and their academic achievement. Discipline related positively with, and accounted for $23 \%$ of variance in the pupils academic performance, however noted that students' academic achievement to some extent depended on their discipline level. Further, Mukami (2013) found a positive relationship between students' discipline and academic achievement in public day secondary schools. The findings indicated that discipline is essential for good learning in schools hence good academic performance. Additonally, the study findings revealed that indiscipline students do not perform well in examinations, violence affects students learning, unrest causes time wastage and indiscipline students lead a bad life after schooling.

The study findings agree with the findings of study by Mussa (2015) on the role of discipline on students' academic performance in Dar es Salaam region in Tanzania, who revealed that best performing schools has suitable school rules and regulation and implement different mechanism, apply fair and consistence punishment, contrary to low performing schools. The study concluded that discipline should be instilled to the students' as it was shown to affect their academic achievement. In the same line, Okoroma, (2015) found that all parameter of school indiscipline that were considered in the study, contributed to low academic achievement of secondary school students.

The results are also consistent with the results of a study by Anya (2016) on the effects of indiscipline on secondary school students in Ethiopia. The study findings revealed that poor results, teenage pregnancy, physical and psychological deformity were glaring effects of students' indiscipline. Similarly Ouma, Serem and Simatwa, (2014) observed that students with indiscipline problems perform poorly in their academics. In the same, Ehiane (2014) who carried out a study on discipline and academic performance in Nigeria, suggested that discipline should be encouraged in controlling students' behavior as it would affect students' general academic performance.

Some studies however disagreed with the current study findings citing that indiscipline has partial influence on students' academic performance. Jones (2013) found that exclusionary students discipline explained only $6 \%$ of variance of the science achievement test schools in later high school while compared to early achievement. This implied that discipline of the students do not contribute much on their academic achievement as the study finding presented. Gakure et., al. (2013) reported the study findings did not show certainly that discipline influences performance because, despite the few minor indiscipline cases reported, performance of primary schools in KCPE in Gatanga was poor.

\section{Conclusion}

The study showed that students' level of indiscipline had a significant negative influence to their academic achievement in the schools under the area of study. It was found that the indiscipline behaviors have contributed to poor academic achievement in the schools. The unacceptable behavior among students prevent them from concentrating in class, lose content and knowledge taught, create tension and insecurity in class as well as 
disrupting lessons leading to use of most of the contact hour in settling disputes. As a result this hinders complete coverage of syllabus before students write their exams (Achiaa et., al., (2018). Majority of the students self-rated average and high in their indiscipline levels. The study revealed that more male fell in the category of highly indiscipline than female. Parents, teachers and the society as whole should therefore corporate and help to reduce incidence of indiscipline behaviors among students. Additionally, parents should meet the social economic needs of their children as this may help them concentrate in learning in order to perform well academically.

This study recommended that secondary school students' indiscipline should be enhanced in Kilifi County, Kenya. Further this study can be replicated with other study variables such as students in rural and urban areas to establish how indiscipline relate or affect students' academic achievement. A comparative study can also be carried out in day and boarding high schools in other counties in the country.

\section{References}

Achiaa, E., Asamoah, E. Ofori, N.K., \& Tordzro, G. (2018) The effects of indiscipline on academic Performance of Junior High school students in Fantaekwa District of Ghana.Wesley College of Education, Kumasi. Journal of Education and practice Vol. 9, No. 21 Retrieved from https://www.researchgate.net/publication

Agak, J., Kabuka E., \& Simba. N., (2016) Impact of discipline on academic achievement performance of pupils in public primary schools in Muhoroni Sub-County, Kenya Journal of education and practice.

Anya k. (2016). The problems of indiscipline on the academic performance of secondary students in Ethiopia East Local Government area. Retrived from https:/www.grossarchive.com

Bandura, A. (1977). Social Learning Theory. Englewood Cliffs, N.J.: Prentice-Hall.

Baumann, C. and Krskova, H. (2016), "School discipline, school uniforms and academic performance", International Journal of Educational Management, Vol. 30 No. 6, pp. 10031029. https://doi.org/10.1108/IJEM-09-2015-0118 Publisher: Emerald Group Publishing Limited Copyright (C) 2016, Emerald Group Publishing Limited

Butcher, K. T. \& Lee, M. M. (2011) Teaching in the Middle Schol (4 ${ }^{\text {th }}$ Edition) Washington DC: American Psychological Association.

Chew, B. H., Zain, A. M., \& Hassan, F. (2013). Emotional intelligence and academic performance in first and final year medical students: a cross-sectional study. BMC Medical Education 2013, 13(44), 2-10

Duckworth, A. L., \& Seligman, M. E. P. (2006). Self-discipline gives girls the edge: gender in self-discipline, grades and achievement scores. Journal of Educational Psychology, 98(1), 198-208.

Espelage, D.L., \& Swearer, S.M. (Eds.). (2011). Bullying in North American schools (2nd edition). New York: Routledge

Ehiane, O. S. (2014). Discipline and academic performance (a study of selected secondary schools in Lagos, Nigeria). International Journal of Academic Research in Progressive Education and Development, 3(1), 181 - 194. Retrieved from http://hrmars.com/hrmars_papers/Discipline_and_Academic_Performance.pdf

Fareo, D., O., \& Ballah, G., A., (2018) Perception of teachers on indiscipline among secondary shool students in Osun State, Nigeria. European Journal of Alternative Education Studies. Vol. 3, issue 1

Gakure, R. W., Mukuria, P., \& Kithae, P. P. (2013). An evaluation of factors that affect performance of primary schools in Kenya: A case study of Gatanga District. Educational Research and Reviews, 8(13), 927- 937. Retrieved from http://www.academicjournals.org/article/article1379769520_Gakure\%20et\%20al.pdf

Gitome, J.W., Katola, M.T., \&Nyabwari, B.G. (2013). Correlation between students' discipline and performance in the Kenya Certificate of Secondary. International Journal of Education and Research, 1(8), 1-10, Retrieved from http://www.ijern.com/journal/August-2013/33.pdf

Jones, J., R., ( 2013) The relationship between early high school discipline and academic outcomes. A dissertation submitted to the applied and professional psychology of Rutgers. The state University of $\mathrm{Ne}$ Jersey

Karuke, E. M. (2012).Influence of Social-cultural and Social-Economic factors on primary school pupils' Discipline in Kilifi District, Kenya; A PhD Thesis submitted to University of Nairobi

Kilifi County Education Office, (2016). Education Statistics.

Kohlberg, L. (1975). Education for society in Moral Transition. New Orrleans, Loisiana. The $30^{\text {th }}$ Annual 
Conference for the Association for supervision of Curriculum Development.

Kute, B. (2014). Teachers Views About Role of Peer Counsellors in Enhancing Student Discipline in Kisumu Municipality Kenya. Research Journal in Organizational Psychology and Educational Studies 3 (3) 209214.

Masitsa, G. (2008). Discipline and disciplinary measures in the Free State Township schools: Unresolved problems. Acta Academia 40 (3): 234270. Available at http://reference sabinet coza/webx/access/electronicjournals/academ/academ-v-40-n3-also-pdfAcessed 13 December 2013.

Mukami, G.K. (2013). Role of discipline on academic achievement among secondary school students in Kiambu County. Kenya; A PhD Thesis submitted to Kenyatta University.

Mwaniki, S., G., (2018) Students indiscipline: A reflection on the causes of misbehavior among learners learners in Kenyan Secondary Schools. Global Journal of advanced Research. Vol. 5, Issue 4 PP. 171-175

Nekby, L., Thoursie, P.S., \& Vahtrik, K. L. (2015). Gender differences in examination behaviour. Economic Inquiry, 53(1), 352-364.

Ngwokabuenui P. Y., (2015) Students' indiscipline: Types, causes and Possible solutions: The case of secondary schools in Cameroon. Journal of Education and Practice.

Njoroge, P.M., \& Nyabuto, A.N. (2014) Discipline as a factor in academic performance in Kenya. Journal of Educational and Social Research. 4(1), 289-307.doi:10.5901/Jesr.2014.v4n/p 289

Nzomo, L.N. (2012). Relationship between principals Emotional Intelligence and students' learning achievements in Public secondary schools in Nairobi County, Kenya; A PhD Thesis submitted to Kenyatta University.

Okoroma, N. S. (2015) School Indiscipline and students' academic achievement: A case study of secondary school in Port Harcourt Local Government Area. River State University of Science and Technology

Omote, M. J., Thinguri, R.W., \& Moenga, M. E. (2015). A critical analysis of acts of student indiscipline and management strategies employed by school authorities in public high schools in Kenya. International Journal of Education and Research, 3(12), 1-10.

Otanga, H. (2016). Challenges in Provision of Free Primary Education in Public Primary in Mombasa County. Retieved from https://www.researchgate.net.

Ouma, M. O., Simatwa, E. W., \& Serem, T. D. K. (2013). Management of pupil discipline in Kenya: A case study of Kisumu Municipality. Educational Research , 4(5) , 374-386. Available at http://www.interesjournals.org/ER

Rahimi, M., \& Karkami, F. H. (2015). The role of teachers' classroom discipline in their Teaching effectiveness and students' language learning motivation and achievement: A path method. Iranian Journal of Language Teaching Research, 3(1), 57-82. Available at www.urmia.ac.ir/ijltr

Umezinwa, R. N., \& Elendu , I . C. (2012). Perception of teachers towards the use of punishment in Sancta Maria Primary School Onitsha, Anambra State, Nigeria. Journal of Education and Practice, 3(2), 4957. Retrieved from www.iiste.org/Journals/index.php/JEP/article/download/1150/1071

Whisman, A., \& Hammer, P.C. (2014).The association between school discipline and mathematics performance: A case study for positive discipline approaches. Charleston, WV: West Virginia Department of Education, Division of Teaching and Learning, Office of Research. West Virginia. Retrieved from https://www.eric.ed.gov 